\title{
Narrative synthesis of psychological and coping responses towards emerging infectious disease outbreaks in the general population: practical considerations for the COVID-19 pandemic
}

Qian Hui $\underline{C h e w}^{1}$, BSocSci(Hons), Ker Chiah $\underline{W e}^{2}$, MBBS, MMed, Shawn Vasoo ${ }^{3}$, MBBS, MRCP, Hong Choon $\underline{C h u a}^{4}$, MBBS, MMed, Kang $\underline{\operatorname{Sim}}^{2}$, MBBS, MMed,

INTRODUCTION Emerging infectious disease outbreaks, such as the present coronavirus disease 2019 (COVID-19) pandemic, often have a psychological impact on the well-being of the general population, including survivors and caregivers. Our study aimed to synthesise extant literature regarding the combined psychological responses and coping methods used by the general population in past outbreaks.

METHODS We conducted a narrative synthesis of the published literature over the last two decades with a quality appraisal of included articles that reported both psychological responses and coping strategies within infectious disease outbreaks. RESULTS A total of 144 papers were identified from the search, 24 of which were included in the review. Overall, 18 studies examined the psychosocial responses of the general population towards the severe acute respiratory syndrome epidemic, four studies focused on the Ebola epidemic and two studies covered the H1N1 outbreak. Common themes in psychological responses included anxiety/fears, depression, anger, guilt, grief and loss, post-traumatic stress and stigmatisation, but also a greater sense of empowerment and compassion towards others. Coping strategies adopted included problem-focused coping (seeking alternatives, self- and other-preservation), seeking social support, avoidance, and positive appraisal of the situation.

CONCLUSION Amid the range of psychosocial responses seen in past infectious disease outbreaks, practical considerations for the current COVID-19 pandemic need to focus on the individual in the context of the larger social environment, with an emphasis on raising awareness of the range of possible psychosocial responses, access to psychological help, selfcare, empowering self-support groups and sustained engagement with updated, reliable information about the outbreak.

Keywords: coping, COVID-19, infectious disease outbreak, psychosocial responses

\section{INTRODUCTION}

The infectious disease outbreaks of recent years have had a significant impact on not only the physical health but also the psychological well-being of communities. ${ }^{(1)}$ The severe acute respiratory syndrome (SARS) outbreak in 2002/2003, H1N1 influenza pandemic in 2009, Middle East respiratory syndrome (MERS) outbreak in 2012 and the current coronavirus disease 2019 (COVID-19) pandemic are all notable infectious disease outbreaks affecting multiple countries and communities. ${ }^{(2)}$ As of 26 March 2020, COVID-19 has affected more than 492,000 people across 198 countries and territories; more than 22,000 people have died from the disease and over 119,000 have recovered at the time of writing. ${ }^{(3)}$ Of note, the general population, including caregivers who are not infected by the disease, is not spared from the psychological consequences of such outbreaks. ${ }^{(4-7)}$ This can be related to various factors including a disruption of the usual routine of life, ${ }^{(8)}$ grief and loss, ${ }^{(9)}$ and stigmatisation experienced during such outbreaks. ${ }^{(10,11)}$ These psychological responses affect the well-being of the individual and community, and can persist long after the outbreak. ${ }^{(12)}$ In the context of the present evolving COVID-19 pandemic, there is a need to synthesise the available information regarding the psychological effects and coping strategies employed during past infectious disease outbreaks in order to understand how we can better support the general public in dealing with this current pandemic.

There are several knowledge gaps to bear in mind. First, the psychosocial responses of patients, survivors, caregivers and the general population could differ from one group to another across outbreaks as the affected population may face unique concerns and experiences during each outbreak. Factors influencing these varying responses also require clarification, as variations in systems of support may be required. Second, it is important to examine different coping responses (adaptive and maladaptive) that have been adopted by the general population, which can have a bearing on overall psychological health.

In light of these knowledge gaps, our study aimed to conduct a narrative synthesis of extant data that documents both the psychological impact and coping responses in the general population (including patients, survivors and caregivers) across past infectious disease outbreaks. We then suggest practical considerations in the current COVID-19 pandemic and possible future research directions.

${ }^{1}$ Research Department, ${ }^{2}$ West Region, Institute of Mental Health, ${ }^{3}$ National Centre for Infectious Diseases, ${ }^{4}$ East Region, Institute of Mental Health, Singapore Correspondence: A/Prof Kang Sim, Senior Consultant, West Region, Institute of Mental Health, 10 Buangkok View, Singapore 539747. kang_sim@imh.com.sg 


\section{METHODS}

We performed a systematic search of the available literature using PubMed, MEDLINE (Ovid), and Web of Science. The following search strategy was used ((psychiatric OR psychological) AND coping) AND (H5N1 OR Nipah OR Ebola OR SARS OR 'severe acute respiratory syndrome' OR H1N1 OR MERS OR 'Middle East respiratory syndrome' OR H7N9), with papers over the past two decades being considered for inclusion. Only studies in the English language and papers from peer-reviewed journals were included. Editorials, commentaries, perspectives, case studies, reviews and dissertations were excluded. Studies that explored coping or psychosocial responses in isolation without relating the two concepts were excluded.

We assessed the quality of articles included in our review using critical appraisal tools for quantitative $\mathrm{e}^{(13)}$ and qualitative ${ }^{(14)}$ studies. The use and modification of such tools can be seen in previous studies on infectious disease outbreaks. ${ }^{(4)}$ We adapted these tools to the needs of our review by inserting the term 'survivors/patients/caregivers/ general population affected by an infectious disease outbreak' and removing the 'intervention' component under McMaster quantitative guidelines. ${ }^{(13)}$ The McMaster University critical appraisal tool ${ }^{(13)}$ was used to appraise quantitative studies, with a score of 1 or 0 given to each of the 11 components. The guidelines by Higginbotham et $\mathrm{al}^{(14)}$ were used to appraise the qualitative studies, with a score of 1 or 0 given to each of the ten components.

\section{RESULTS}

We identified 95 (PubMed) and 49 papers (Web of Science) from the database search, of which 24 papers (21 from PubMed, 3 from Web of Science) were included in the review. A PRISMA flow diagram depicting how articles were selected is presented in Fig. 1. Of the 24 included articles, ten were qualitative studies, 12 were quantitative studies, and two employed a mixed methods design. Overall, 18 studies examined the SARS epidemic, four studies focussed on the Ebola epidemic and two studies covered the H1N1 pandemic (Appendix, Supplementary Table I).

\section{Quality appraisal}

Of the 14 quantitative studies evaluated (12 employing only quantitative surveys and two mixed methods), all studies scored at least ten out of a maximum possible of 12 (Appendix, Supplementary Table II). Several studies failed to adequately report dropouts, exclusions or response rates. ${ }^{(7,15-18)}$ Of the 12 qualitative studies evaluated (ten qualitative interviews and two mixed methods), all studies scored at least nine out of a maximum possible of ten (Appendix, Supplementary Table III). Although most of the studies mentioned how data was recorded and kept, aspects relating to data management and storage (e.g. whether data was destroyed after the study ended) were inadequately reported in some studies.

\section{Common themes across infectious disease outbreaks Psychological responses}

Anxiety and somatic symptoms

The presence of anxiety and/or fears was a common theme, with rates varying between $3.2 \%$ and $12.6 \%$ across 11 out of 18

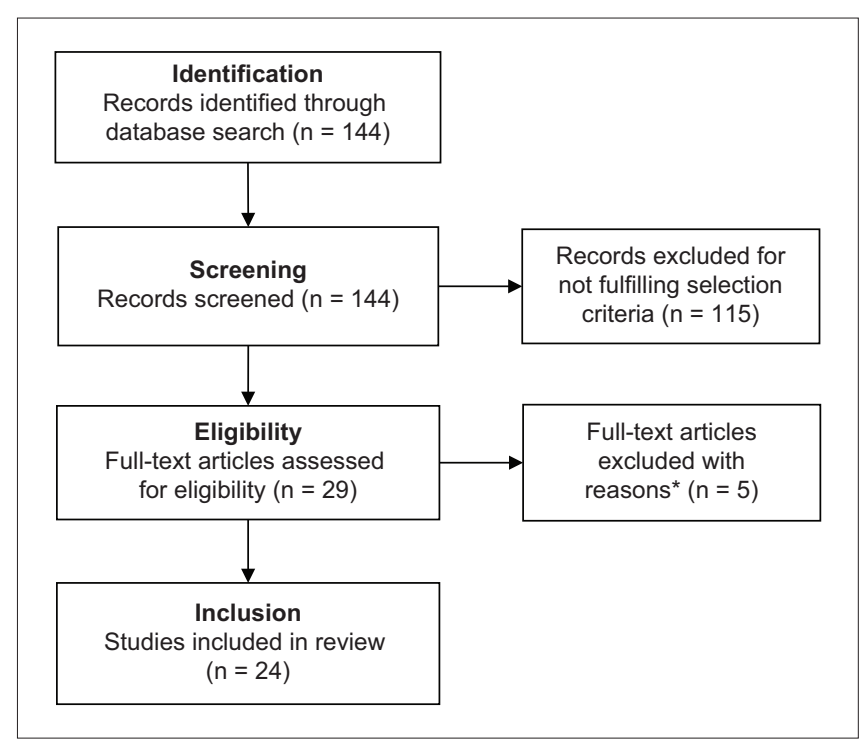

Fig. 1 PRISMA flowchart shows the literature search and study selection process for psychological and coping responses towards emerging infectious disease outbreaks in patients and the general public. *Five articles looked at psychological responses or coping strategies in isolation. PRISMA: preferred reporting items for systematic reviews and metaanalyses

SARS-related studies, ${ }^{(6,8,19-27)}$ both H1N1-related studies, ${ }^{(7,28)}$ and two out of four Ebola-related studies. ${ }^{(29,30)}$

Anxiety levels of survivors were significantly higher than those of the general community, with $7.3 \%$ of the SARS survivors in Cheng et al's study ${ }^{(20)}$ reporting Beck Anxiety Inventory scores in the severe range. Almost $60 \%$ of the nationwide Taiwanese sample were worried about the recurrence of SARS, and $3.2 \%$ of them met the criteria for psychological distress based on Brief Symptom Rating Scale scores. ${ }^{(25)}$ Higher rates were reported from a general community sample in Hong Kong, with $12.6 \%$ of them feeling 'quite' or 'very' anxious based on the State-Trait Anxiety Inventory scores. ${ }^{(23)}$

Somatic symptoms were reported in three out of 18 SARS-related studies, ${ }^{(20,25,31)}$ and in one of the four Ebola-related studies. ${ }^{(11)}$ SARS survivors had higher levels of somatic symptoms compared to community subjects. ${ }^{(20)}$ Clinically significant levels of sleep disturbance were reported in $4.2 \%$ of a nationwide Taiwanese sample. ${ }^{(25)}$ For residents living at the epicentre of the SARS outbreak, about $34 \%$ of those experiencing psychosomatic responses reported insomnia as well. ${ }^{(31)}$

Apart from the fear of another outbreak, ${ }^{(25)}$ other reasons cited for increased anxiety included beliefs that one was more vulnerable to the infection, ${ }^{(26)}$ uncertainty regarding the treatment process and outcomes, ${ }^{(8,24)}$ the well-being of loved ones and their economic situation, ${ }^{(30)}$ separation from loved ones, disruption in work life, and having to juggle multiple responsibilities as a caregiver. ${ }^{(8)}$ In contrast, Joffe and Haarhoff ${ }^{(29)}$ reported that although almost half of the general population sample in Britain recognised that the Ebola outbreak was a fearful disease, very few people expressed personal anxiety over the outbreak.

\section{Depressive symptoms}

Depressive symptoms with rates ranging from $3.0 \%$ to $73.1 \%$ were specifically observed in six out of 18 studies pertaining to 
SARS $^{(15,21,24,25,27,31)}$ and two studies on the Ebola epidemic. ${ }^{(11,30)}$ The presence of helplessness or hopelessness, which are cognitive features of depression, were also seen in three SARS-related studies $^{(18,21,24)}$ and both Ebola-related studies. ${ }^{(11,30)}$ In a nationwide Taiwanese sample, $3.0 \%$ met the criteria for psychological distress due to depression, ${ }^{(25)}$ and $73.1 \%$ of Hong Kong residents staying at the epicentre of the outbreak reported more than two weeks of low mood following the outbreak. ${ }^{(31)}$

Reasons associated with depressive symptoms include an inability to return to their usual routine of life, ${ }^{(30)}$ the contagiousness of the disease, lack of information regarding its route of transmission, stigma, and proximity to the epicentre of the outbreak. ${ }^{(31)}$ In particular, the extreme role change experienced by healthcare workers who later became patients after contracting SARS was associated with a sense of helplessness. ${ }^{(24)}$ Survivors of Ebola and their family members also viewed the disease and subsequent death as inescapable, which conveyed a sense of hopelessness. ${ }^{(11)}$

Feelings of anger and irritability with rates ranging from $2.3 \%$ to $56.7 \%$ were reported in five SARS-related studies. ${ }^{(22,24,25,27,31)}$ Of note, $2.3 \%$ and $2.9 \%$ of a nationwide Taiwanese sample had clinically significant levels of hostility and inferiority respectively. ${ }^{(25)}$ Younger and middle-aged adults appeared to experience higher levels of anger as compared to older adults. ${ }^{(27)}$ Anger and frustration was attributed to lack of and conflicting information regarding the disease, ${ }^{(22,31)}$ as well as feelings of isolation and stigmatisation that persisted even after discharge. ${ }^{24,31)}$

Grief and loss experienced at multiple levels featured more prominently in studies of Ebola and were reported in two studies. ${ }^{(9,30)}$ This was a result of not only the death of loved ones ${ }^{(9,30)}$ but also a loss of one's cultural identity, rituals ${ }^{(9)}$ and material possessions. ${ }^{(30)}$ Loss as experienced by those affected during the SARS and H1N1 outbreaks was often related to a loss of one's usual way of life. In a sample of residents living at the epicentre of the SARS outbreak in Hong Kong, 88.1\% felt that the outbreak had severely affected their daily life. ${ }^{(31)}$ Healthcare workers who later became infected felt the loss in the occupational sphere of life as they transitioned from the role of a healthcare provider to that of a patient. ${ }^{(24)}$ Patients also reported experiencing a loss of control due to the lack of information available regarding the disease and treatment process. ${ }^{(24)}$

In terms of longitudinal changes, negative cognitions and emotional responses tended to decline over time. ${ }^{(18)}$ In particular, older adults experienced a greater decline in sadness about two months after the outbreak as compared to younger adults. ${ }^{(27)}$ The nature of concerns reported by respondents also changed over time. Possible factors included one's geographical distance from the outbreak ${ }^{(18)}$ and use of coping strategies. ${ }^{(27)}$ Situation-specific coping strategies (personal hygiene practices and avoidance of crowds) were more predictive of changes in anxiety levels as compared to lifestyle habits or informationseeking behaviour. ${ }^{(19)}$

\section{Post-traumatic stress symptoms}

Post-traumatic stress symptoms (25.8\%) were reported in one SARS-related ${ }^{(6)}$ and two Ebola-related studies. ${ }^{(11,30)}$ Survivors of
Ebola and their caregivers reported lingering feelings of fear and low mood after the outbreak and re-experienced them during subsequent disease outbreaks. ${ }^{(11)}$ Many Ebola survivors also reported flashbacks, particularly those involving images of corpses. ${ }^{(30)}$ In a sample of the general population in Singapore, $25.8 \%$ of the respondents experienced post-traumatic morbidity following a SARS outbreak as well. ${ }^{(6)}$

\section{Stigmatisation, abandonment and isolation}

Experiences of stigmatisation, abandonment and isolation (rates of $9.7 \%-48.7 \%$ ) were noted in seven SARS-related studies, ${ }^{(22,24-26,31,32)}$ one H1N1-related study ${ }^{(28)}$ and all four Ebola-related studies.

In a general population sample of Taiwanese residents, 9.7\% reported that they, their family or their friends had experienced SARS-related discrimination because they had been quarantined or had family members who were healthcare workers. ${ }^{(25)}$ Residents living at the epicentre of the outbreak in Hong Kong experienced more severe stigmatisation, with $40.6 \%$ being rejected for dining with friends, $48.7 \%$ experiencing workplace discrimination from employers, and $47.8 \%$ from colleagues. ${ }^{(31)}$

Stigmatisation resulted not only from one's identity as a survivor or relationship to a survivor, ${ }^{(11,25,30,33)}$ but also one's nationality, ${ }^{(28,29)}$ place of residency ${ }^{(31)}$ and health status prior to the outbreak. ${ }^{(26)}$ Those having chronic illnesses prior to the outbreak were identified as being particularly vulnerable to SARS, resulting in discriminatory attitudes towards them. ${ }^{(26)}$ Latinos were stigmatised as Mexico was determined to be the epicentre of the H1N1 outbreak. ${ }^{(28)}$ Attitudes of the general population were particularly influenced by media portrayals. ${ }^{(26,29)}$

Feelings of abandonment and isolation often result from experiences of stigma and discrimination. Survivors reported feeling abandoned when they were turned away from healthcare services, ${ }^{(9)}$ ostracised by their community ${ }^{(9,30)}$ and distanced from healthcare workers due to the use of personal protective equipment (PPE). . $^{(9,22)}$

Feelings of isolation often arose as a result of having to be quarantined. ${ }^{(30)}$ Despite most patients understanding the need for quarantine measures, being quarantined evoked feelings of abandonment that sometimes lasted beyond discharge. ${ }^{(24)}$ These quarantine measures also affected those who were not exposed to the virus, such as new mothers who had to be separated from their infant. ${ }^{(22)}$ Immigrants were particularly worried about how quarantine measures would affect their community and result in further isolation. ${ }^{(28)}$

\section{Positive changes and cognitive restructuring}

Positive changes and post-traumatic growth as a result of the outbreak were seen in four SARS-related studies ${ }^{(21,24,32,33)}$ and one Ebola-related study. ${ }^{(30)}$ Some survivors gained self-empowerment through the ordeal, transcending victimhood. ${ }^{(11,33)}$ This took the form of having increased compassion, being present for others despite the fear, showing empathy even to those who discriminated against them, ${ }^{(33)}$ and educating others about the outbreak. ${ }^{(30)}$ Survivors also reported a change in perspective on life and their occupational roles. Some began to redefine their 
life priorities, ${ }^{(24)}$ while healthcare workers who fell ill began to understand the importance of providing psychological support during times of crisis. ${ }^{(24,33)}$

\section{Coping responses}

\section{Problem-solving}

Alternatives were sought when healthcare services were not accessible or limited. Some respondents sought complementary medicine when healthcare services were not accessible or when they were refused treatment. ${ }^{(9)}$ Others sought alternative measures such as qigong, recognising the limitations of biomedical treatment. ${ }^{(26)}$ This coping strategy allowed them to take active steps towards self-empowerment and reduced feelings of uncertainty by providing a sense of control over their health. ${ }^{(26)}$

Respondents engaged in behaviours they believed would serve to protect themselves or others. This took the form of infection control measures ${ }^{(19,28)}$ such as cleaning their homes with hygiene supplies ${ }^{(11,22)}$ and changing their healthcare decisionmaking process. ${ }^{(22)}$ Some even took care of family members, acquaintances or strangers who were infected by the disease. ${ }^{(9)}$ Other measures that were adopted included increased monitoring of information pertaining to the outbreak ${ }^{(19,22)}$ and self-isolation. Some chose to self-isolate when they suspected that they had contracted the disease in order to prevent its spread. ${ }^{(9)}$ Others isolated themselves from healthcare workers in an act of selfpreservation $^{(9,17,19,33)}$ or to avoid placing more burden on others during this stressful period. ${ }^{(8)}$ To avoid discrimination and stigma, respondents hid their status as a survivor or their place of residency when seeking employment, and some even chose to relocate. ${ }^{(31)}$

\section{Seeking social support}

One of the common strategies adopted by respondents was seeking social support. ${ }^{(15,16,20,24,27,32)}$ Such communities of support were formed when respondents sought alternative treatment ${ }^{(26)}$ and when fellow patients and survivors came together for mutual support. ${ }^{(30,31)}$ The presence of supportive healthcare workers was comforting to patients and survivors. ${ }^{(24,30)}$ Many also found prayer and support from the religious community to be helpful. . $^{(11,24,28,30)}$

\section{Distraction, denial or avoidance}

Some respondents found ways to distract themselves from the situation by performing external actions, while some others resorted to mental avoidance. ${ }^{(6,8,9,15,17,24,27,28,30,32)}$ Some Ebola patients ran away from their town, ${ }^{(9)}$ while others kept themselves busy looking for jobs or reading. ${ }^{(30)}$ Caregivers distracted themselves by going out to buy the patients' favourite food. ${ }^{(8)}$ Some survivors mentally disengaged from the traumatising situation in the treatment unit and experienced a sense of numbness, ${ }^{(30)}$ while members of the general public denied the significance of the pandemic after being overwhelmed by information ${ }^{(28)}$ or expressed wishful thinking. ${ }^{(17)}$ Nurses who were eventually diagnosed with SARS tended to reject the possibility of the diagnosis even when they started feeling unwell. ${ }^{(24)}$ $\underline{\text { Positive appraisals }}$

Respondents tried adopting a positive attitude in the face of the crisis. ${ }^{(6,11,15,27,32)}$ For example, some chose to seek alternative treatment and prevention methods, ${ }^{(26)}$ which reflected an internal locus of control. ${ }^{(7,26)}$ The confidence that respondents placed in their government's ability to manage the situation ${ }^{(25)}$ or their healthcare system ${ }^{(23,29)}$ also reflected a positive appraisal of the situation. Some attempted to reappraise the situation through a culturally relevant lens, using stories from past outbreaks in their cultural community to understand what to anticipate and reduce distress. ${ }^{(28)}$

\section{Correlations between variables Demographic factors, perception of risk and psychological distress}

Demographic factors were correlated with psychiatric distress as well. Survivors who were healthcare workers, ${ }^{(20,21)}$ had a chronic illness ${ }^{(26)}$ or had lost family members were significantly more likely to experience high distress. ${ }^{(30)}$ Older adults were more likely to experience psychological distress, according to a study by Peng et $\mathrm{al}^{\left({ }^{(25)}\right.}$ although Main et $\mathrm{al}^{(15)}$ found a negative correlation between age and disease-related stressors. Those with a higher level of education had better mental health $(p<0.01)^{(16)}$ and less negative emotions $(p<0.05) .{ }^{(18)}$

Perception of risk was positively correlated with psychological symptoms $(r=0.12, p \leq 0.01) .{ }^{(15)}$ Specifically, the fear of a recurrent outbreak was predictive of psychological distress (odds ratio $[\mathrm{OR}] 1.48,95 \%$ confidence interval $[\mathrm{Cl}] 1.02$ to 2.16$),{ }^{(25)}$ as were concerns about losing control of the spread of SARS, contracting SARS and the health of one's family. ${ }^{(6)}$ On the other hand, post-traumatic morbidity was not associated with these concerns. ${ }^{(6)}$ Appraisals of the perceived impact of the epidemic, ${ }^{(21)}$ particularly the level of threat $(r=0.59, p<0.01)$, self- and othercontrol regarding the virus ${ }^{(7)}$ and one's coping efficacy, ${ }^{(16,21)}$ were predictive of anxiety, ${ }^{(7)}$ depression, ${ }^{(21)}$ and overall mental health and functioning. ${ }^{(16)}$

Perceived general health $(r=-0.46, p \leq 0.001)$ and life satisfaction $(r=-0.31, p \leq 0.001)$ were negatively correlated with psychological symptoms. ${ }^{(15)}$

\section{Demographic factors, risk appraisal and coping strategies}

Age was negatively correlated with active coping $(r=-0.14$, $p \leq 0.05)$ and seeking social support $(r=-0.12, p \leq 0.05) .{ }^{(15)} \mathrm{A}$ mediating factor may be the phase of the outbreak, as younger adults reported using more emotion-focused coping at the acute phase of the outbreak, while older adults used more emotionfocused coping several months after the outbreak. ${ }^{(27)}$

Appraisals of threat ${ }^{(17)}$ and personal vulnerability predicted the adoption of active coping strategies ${ }^{(26)}$ such as infection control measures (OR 1.50, 95\% Cl 1.07-2.09). ${ }^{(23)}$ Appraisals of self- and other-control during the outbreak were negatively correlated with the use of emotion-focused strategies $(p<0.01$ and $p<0.05$, respectively) and positively correlated with the use of problemfocused strategies (both $\mathrm{p}<0.01$ ). ${ }^{(7)}$ Respondents who perceived the negative effects of the outbreak to be more severe had lower 
levels of defensiveness or denial. ${ }^{(32)}$ Active coping was positively related to perceived general health $(r=0.12, p \leq 0.05)$ and life satisfaction $(r=0.17, p \leq 0.001) .{ }^{(15)}$ Seeking social support was positively correlated with life satisfaction $(r=0.11, p \leq 0.05)$, while rumination and worry resulted in less problem-focused coping $(r=-0.34, p<0.001) .{ }^{(15)}$

\section{DISCUSSION}

Our study aimed to explore the psychosocial responses in survivors, caregivers and the general population during an infectious disease outbreak. We identified several common themes in psychological responses across the outbreaks, including anxiety/fears, depression, anger, guilt, grief and loss, post-traumatic stress, and stigmatisation but also positive changes and cognitive restructuring. Common coping strategies included problem-focused coping (seeking alternatives, self- and otherpreservation), seeking social support, avoidance and positive appraisal of the situation.

\section{Comparison across outbreaks Psychological distress}

Fears, anxieties and depression were common psychological symptoms reported across outbreaks. Underlying reasons cited for these symptoms included disruptions in daily routine, the uncertainty involving one's job and financial security, their loved ones' well-being, the treatment process, and information pertaining to the disease. Post-traumatic stress symptoms, on the other hand, differed more significantly across outbreaks. Studies exploring the impact of the Ebola epidemic, in particular, often featured post-traumatic stress symptoms as a main theme. This could possibly be explained by the higher mortality rate for the Ebola outbreak $(50 \%)$ compared with SARS $(15 \%)^{(34,35)}$ and $\mathrm{H} 1 \mathrm{~N} 1(0.02 \%),{ }^{(36)}$ and the disparity in quality and accessibility of healthcare services in affected regions. Ebola-related studies in our review were concentrated in West Africa, where the quality and accessibility of healthcare services are often lacking as compared to developed nations where the SARS and H1N1 outbreaks occurred. This resulted in poor handling of bodies postmortem and a situation in which survivors had to spend an extended period of time in the same treatment unit as those who had already passed away. ${ }^{(9,30)}$ This contributed to post-traumatic stress symptoms such as flashbacks involving images of corpses. ${ }^{(30)}$ Issues with the healthcare system and implementation of infection control measures also meant that the mortality rate and likelihood of transmitting the virus within families and communities were higher for Ebola virus outbreaks. Hence, respondents were more likely to have experienced grief and loss from the death of a loved one. ${ }^{(9,11,30)}$ Whereas the nature of loss as experienced by respondents involved in the Ebola outbreak were largely focused on the physical (i.e. people and possessions), ${ }^{(30)}$ those affected in the SARS and H1N1 outbreaks often reported losses involving aspects of daily life, such as a disruption in their daily routine or social support. ${ }^{(22)}$

Despite the possible differences in culture, education levels and healthcare services available, stigma and abandonment were reported across various outbreaks. One plausible explanation for this is that the various communities lacked information or experience on these emerging infectious diseases at the start and ways to handle the situation. Large-scale infectious disease outbreaks of high severity were still uncommon to most countries. This resulted in issues regarding the dissemination of health information in an appropriate and accurate manner. ${ }^{(8,24,26,28,29)}$ Media portrayals, in particular, appeared to have a strong influence on discriminatory attitudes directed towards selected groups of people, such as the chronically ill(26) and those of a certain nationality. ${ }^{(28,29)}$

\section{Coping strategies}

The use of different coping methods (e.g. problem-solving, seeking social support, distraction/denial/avoidance and positive thinking) ${ }^{(37)}$ in reducing psychological distress differed across studies. Problem-solving reduced sadness in a study by Yeung and Fung, ${ }^{(27)}$ but was unrelated to ${ }^{(7)}$ or contributed to an increase in anxiety levels in other studies. ${ }^{(19)}$ Conflicting results could be explained in relation to one's appraisal of the situation. Lazarus and Folkman (38) suggested that a 'goodness of fit' had to be achieved between one's appraisal of the situation and the selected coping strategy to maximise its effectiveness. The use of problemfocused strategies such as problem-solving should predict better adjustment in controllable situations, while emotion-focused strategies such as avoidance and denial would be favoured in uncontrollable situations. ${ }^{(38)}$ Notably, attempts at problem-solving resulted in a decline in sadness only for the older adult group in Yeung and Fung's $\mathrm{s}^{(27)}$ study. This could indicate that older adults who may have had more experience dealing with health issues and previous encounters with infectious disease outbreaks appraised the situation as being controllable, more so than the younger and middle-aged adults. Across studies, survivors found solace in religious practices, the presence of empathetic healthcare workers throughout their treatment and discharge, and the support of fellow survivors. ${ }^{(9,11,24,30)}$ Attempts to cope through positive thinking and appraisals were reflected across studies, with the general population putting their confidence in alternative treatments, the government or the healthcare system. ${ }^{23,25,29)}$

\section{Practical considerations in the current COVID-19 pandemic}

The current COVID-19 pandemic is unique in its high transmissibility; potential infectivity through mildly symptomatic individuals; severe complications in the elderly, those with medical comorbidities and even the younger population; and the absence of vaccine and proven biological therapies at the time of writing. ${ }^{(39)}$ Yet, one must not lose track of the possible responses of affected individuals in the bid to contain the outbreak. ${ }^{(40)}$ In view of the likely prolonged nature of the pandemic and range of psychosocial responses that can occur, ${ }^{(11)}$ it is important to raise awareness among the general population and healthcare providers about its clinical manifestations. ${ }^{(10)}$ Second, awareness of these psychosocial responses would allow early identification of individuals who may need further psychological assistance in 
the event that these responses are persistent, unusually intense, pervasive across different settings and impair daily functioning of the individual. This also highlights the need to maintain the continuity of mental health services, especially of those with pre-existing mental illness and who may be affected by the COVID-19 pandemic. Third, access to psychological help should be made available whenever needed, with sensitivity to specific arrangements in relation to the pandemic such as special work arrangements, quarantine orders, stay-home notice, leave of absence, medical leave and hospitalisation for COVID-19 treatment. Fourth, it is important to encourage adaptive coping responses $^{(15)}$ such as self-care, ${ }^{(16)}$ which includes adequate rest, spending time with loved ones, recreational activities within official advisory limits or upskilling, which can be done online. ${ }^{(9)}$ Fifth, it is useful to empower peer and community support groups to look out for one another during such times of anxiety, frustration, uncertainty, isolation and stigmatisation..$^{(11,12,16)}$ In view of the need to observe physical distancing, leveraging on technology and social media to facilitate responsive and real-time outreach for greater connectivity would be useful in overcoming social isolation. Encouraging such prosocial behaviours may promote more adaptive responses during a stressful period such as the current pandemic and prevent more automatic and unhelpful responses. ${ }^{(17)}$ Sixth, there needs to be sustained engagement in terms of access to updated, verifiable information about the outbreak due to its likely enduring trajectory, the ubiquity of social media and subjective reporting, and evolving illness dynamics internationally. ${ }^{(41,42)}$ Seventh, it is crucial to maintain a spirit of perseverance and optimism to weather the pandemic, which will pass like previous pandemics.

\section{Implications for further research}

Several areas are worth noting. First, it would be meaningful to examine the psychosocial responses of different subgroups in the population that have been affected by the outbreak across different occupations and seniority, and of those affected by control measures such as quarantine orders. This would allow us to have a more comprehensive understanding of its impact. Second, prospective studies are needed to assess changes in psychosocial responses over time and the relationship to demographic profiles, risk perception or exposure status to current pathogens in daily routines and work. Third, it would be useful to examine the impact and relationship of social media to various psychosocial responses, as these information-sharing platforms were not as prevalent during past infectious disease outbreaks. Fourth, understanding how experiences of previous outbreaks influence current psychosocial responses would allow targeted efforts to ameliorate these underlying factors.

In conclusion, this review aimed to synthesise the psychosocial responses (psychological responses and coping methods) in the general population, survivors and caregivers across previous infectious disease outbreaks. Psychological responses included anxiety, depression, loss, stigmatisation, isolation and cognitive restructuring. The extent to which each type of coping strategy was helpful for relieving psychological distress was associated with varied factors, including one's risk appraisal, demographic factors and severity of the outbreak. Practical considerations for the current pandemic need to focus on the individual in the context of the larger social environment, with an emphasis on raising awareness of the range of possible psychosocial responses, access to psychological help, self care and sustained engagement. Further research endeavours should seek to understand the longitudinal psychological impact of disease outbreaks, differences in psychosocial responses among population subgroups, interrelationships with social media, and the influence of past experiences with infectious disease outbreaks, in order to better prepare ourselves psychologically to face future outbreaks.

\section{SUPPLEMENTARY MATERIAL}

The Appendix is available online at https://doi.org/10.11622/ smedj.2020046.

\section{REFERENCES}

1. Sim K, Chua HC. The psychological impact of SARS: a matter of heart and mind. CMAJ 2004; 170:811-2.

2. Lum LHW, Tambyah PA. Outbreak of COVID-19 - an urgent need for good science to silence our fears? Singapore Med J 2020; 61:55-7.

3. Worldometer. COVID-19 Coronavirus Pandemic. Available at: https://www. worldometers.info/coronavirus/. Accessed March 26, 2020.

4. James PB, Wardle J, Steel A, Adams J. Post-Ebola psychosocial experiences and coping mechanisms among Ebola survivors: a systematic review. Trop Med Int Health 2019; 24:671-91.

5. Lee TM, Chi I, Chung LW, Chou KL. Ageing and psychological response during the post-SARS period. Aging Ment Health 2006; 10:303-11.

6. Sim K, Chan YH, Chong PN, Chua HC, Soon SW. Psychosocial and coping responses within the community health care setting towards a national outbreak of an infectious disease. J Psychosom Res 2010; 68:195-202.

7. Taha S, Matheson K, Cronin T, Anisman H. Intolerance of uncertainty, appraisals, coping, and anxiety: the case of the $2009 \mathrm{H} 1 \mathrm{~N} 1$ pandemic. Br J Health Psychol 2014; 19:592-605.

8. Chan SS, Leung D, Chui $\mathrm{H}$, et al. Parental response to child's isolation during the SARS outbreak. Ambul Pediatr 2007; 7:401-4.

9. Schwerdtle PM, De Clerck V, Plummer V. Experiences of Ebola survivors: causes of distress and sources of resilience. Prehosp Disaster Med 2017; 32:234-9.

10. Kamara S, Walder A, Duncan J, et al. Mental health care during the Ebola virus disease outbreak in Sierra Leone. Bull World Health Organ 2017; 95:842-7.

11. Matua GA, Wal DM. Living under the constant threat of Ebola: a phenomenological study of survivors and family caregivers during an Ebola outbreak. J Nurs Res 2015; 23:217-24.

12. Lau AL, Chi I, Cummins RA, et al. The SARS (Severe Acute Respiratory Syndrome) pandemic in Hong Kong: effects on the subjective wellbeing of elderly and younger people. Aging Ment Health 2008; 12:746-60.

13. Law M, Steinwender S, Leclair L. Occupation, health and well-being. Can J Occup Ther 1998; 65:81-91.

14. Higginbotham N, Albrecht G, Connor L. Health social science: a transdisciplinary and complexity perspective. The University of Newcastle's Digital Repository. Newcastle, Australia: Oxford University Press, 2001.

15. Main A, Zhou Q, Ma Y, Luecken LJ, Liu X. Relations of SARS-related stressors and coping to Chinese college students' psychological adjustment during the 2003 Beijing SARS epidemic. J Couns Psychol 2011; 58:410-23.

16. Mak WW, Law RW, Woo J, Cheung FM, Lee D. Social support and psychological adjustment to SARS: the mediating role of self-care self-efficacy. Psychol Health 2009; 24:161-74.

17. Puterman E, Delongis A, Lee-Baggley D, Greenglass E. Coping and health behaviours in times of global health crises: lessons from SARS and West Nile. Glob Public Health 2009; 4:69-81.

18. Qian M, Ye D, Zhong J, et al. Behavioural, cognitive and emotional responses to SARS: differences between college students in Beijing and Suzhou. Stress Health $2005 ; 21: 87-98$.

19. Cheng C, Cheung MW. Psychological responses to outbreak of Severe Acute Respiratory Syndrome: a prospective, multiple time-point study. J Pers 2005; 73:261-85

20. Cheng SK, Sheng B, Lau KK, et al. Adjustment outcomes in Chinese patients following one-month recovery from Severe Acute Respiratory Syndrome in Hong Kong. J Nerv Ment Dis 2004; 192:868-71.

21. Cheng SK, Chong GH, Chang SS, et al. Adjustment to severe acute respiratory 
syndrome (SARS): roles of appraisal and post-traumatic growth. Psychol Health 2006; 21:301-17.

22. Dodgson JE, Tarrant M, Chee YO, Watkins A. New mothers' experiences of social disruption and isolation during the Severe Acute Respiratory Syndrome outbreak in Hong Kong. Nurs Health Sci 2010; 12:198-204.

23. Leung GM, Lam TH, Ho LM, et al. The impact of community psychological responses on outbreak control for Severe Acute Respiratory Syndrome in Hong Kong. J Epidemiol Community Health 2003; 57:857-63.

24. Mok E, Chung BP, Chung JW, Wong TK. An exploratory study of nurses suffering from severe acute respiratory syndrome (SARS). Int J Nurs Pract 2005; 11:150-60.

25. Peng EY, Lee MB, Tsai ST, et al. Population-based post-crisis psychological distress: an example from the SARS outbreak in Taiwan. J Formos Med Assoc 2010; 109:524-32

26. Siu JY, Sung HC, Lee WL. Qigong practice among chronically ill patients during the SARS outbreak. J Clin Nurs 2007; 16:769-76.

27. Yeung DY, Fung $\mathrm{HH}$. Age differences in coping and emotional responses toward SARS: a longitudinal study of Hong Kong Chinese. Aging Ment Health 2007; 11:579-87.

28. McCauley M, Minsky S, Viswanath $\mathrm{K}$. The H1N1 pandemic: media frames, stigmatization and coping. BMC Public Health 2013; 13:1116.

29. Joffe H, Haarhoff $\mathrm{G}$. Representations of far-flung illnesses: the case of Ebola in Britain. Soc Sci Med 2002; 54:955-69.

30. Rabelo I, Lee V, Fallah MP, et al. Psychological distress among Ebola survivors discharged from an Ebola treatment unit in Monrovia, Liberia - a qualitative study. Front Public Health 2016; 4:142.

31. Lee S, Chan LY, Chau AM, Kwok KP, Kleinman A. The experience of SARSrelated stigma at Amoy Gardens. Soc Sci Med 2005; 61:2038-46.
32. Cheng C, Wong WM, Tsang KW. Perception of benefits and costs during SARS outbreak: an 18-month prospective study. J Consult Clin Psychol 2006; 74:870-9.

33. Chiang $\mathrm{HH}$, Chen MB, Sue IL. Self-state of nurses in caring for SARS survivors. Nurs Ethics 2007; 14:18-26.

34. World Health Organization. Update 49 - SARS case fatality ratio, incubation period. In: Emergencies preparedness, response [online] 2003. Available at: https://www.who.int/csr/sarsarchive/2003_05_07a/en/. Accessed March 18, 2020

35. World Health Organization. Ebola virus disease. In: World Health Organization [online] 2020. Available at: https://www.who.int/news-room/fact-sheets/detail/ ebola-virus-disease. Accessed March 18, 2020.

36. Simonsen L, Spreeuwenberg P, Lustig R, et al. Global mortality estimates for the 2009 influenza pandemic from the GLaMOR project: a modeling study. PLoS Med 2013; 10:e1001558.

37. Baumstarck K, Alessandrini M, Hamidou Z, et al. Assessment of coping: a new French four-factor structure of the brief COPE inventory. Health Qual Life Outcomes 2017; 15:8.

38. Lazarus RS, Folkman S. Stress, Appraisal, and Coping, New York, NY: Springer, 1984.

39. Wong JEL, Leo YS, Tan CC. COVID-19 in Singapore-current experience: critical global issues that require attention and action. JAMA 2020 Feb 20. https://doi. org/10.1001/jama.2020.2467. [Epub ahead of print]

40. Low JG, Wilder-Smith A. Infectious respiratory illnesses and their impact on healthcare workers: a review. Ann Acad Med Singapore 2005; 34:105-10.

41. Depoux A, Martin S, Karafillakis E, et al. The pandemic of social media panic travels faster than the COVID-19 outbreak. J Travel Med 2020 Mar 3; pii:taaa031. 42. Shimizu K. 2019-nCoV, fake news, and racism. Lancet 2020; 395:685-6. 
Supplementary Table I. Summary of main findings of studies on combined psychological and coping responses among emerging ID (SARS, Ebola, H1N1) outbreaks.

\begin{tabular}{|c|c|c|c|c|c|c|}
\hline No. & Author (yr) & ID & Population & Sociodemographic features & Method and Measures used & Main Findings \\
\hline 1 & Main et al (2011) & SARS & $\begin{array}{l}\text { Undergraduate students from } 2 \text { public } \\
\text { universities in Beijing }\end{array}$ & $\begin{array}{l}381 \text { undergraduate students, } 42.5 \% \mathrm{M} \\
\text { Mean age: } 20.16 \pm 1.46 \mathrm{yr} \\
\text { - } 238 \text { first-year students }(60.8 \%) \\
\text { - } 63 \text { sophomores }(16.1 \%) \\
\text { - } 47 \text { juniors }(12.0 \%) \\
\text { seniors }(11.0 \%)\end{array}$ & $\begin{array}{l}\text { Self-report using an anonymous survey relating } \\
\text { to: } \\
\text { - SARS-related stressors } \\
\text { - Coping strategies } \\
\text { - Psychological symptoms } \\
\text { - Perceived general health } \\
\text { - Life satisfaction }\end{array}$ & $\begin{array}{l}\text { Psychological responses } \\
\text { Main effect of SARS-related stressors was a positive and significant predictor of } \\
\text { psychological symptoms (somatisation, obsessive-compulsive, depressive and } \\
\text { phobic/anxiety symptoms) } \\
\text { Coping responses } \\
\text { Avoidant coping }(\beta=0.24, p \leq 0.001 \text { ) and seeking social support coping ( } \beta= \\
0.14, p \leq 0.001) \text { positively predicted psychological symptoms when controlling } \\
\text { for SARS-related stressors and covariates }\end{array}$ \\
\hline 2 & $\begin{array}{l}\text { Dodgson et al } \\
\text { (2010) }\end{array}$ & SARS & $\begin{array}{l}\text { Women who became mothers during } \\
\text { the SARS outbreak in Hong Kong in } \\
2003\end{array}$ & $\begin{array}{l}8 \text { Chinese mothers living in Hong Kong } \\
\text { who delivered healthy newborn infants } \\
\text { during the SARS outbreak } \\
\text { Age range: } 28-38(34.29 \pm 3.20) \text { yr } \\
6(75 \%) \text { participants were first-time } \\
\text { mothers }\end{array}$ & $\begin{array}{l}\text { Qualitative study to discuss experiences of } \\
\text { being pregnant and delivering their baby } \\
\text { during the SARS epidemic }\end{array}$ & $\begin{array}{l}\text { Psychological responses } \\
\text { - Living with uncertainty } \\
\text { - Intense vigilance } \\
\text { - Social isolation } \\
\text { - Disrupted expectations } \\
\text { Coping responses } \\
\text { Problem-focused coping }\end{array}$ \\
\hline 3 & Peng et al (2010) & SARS & $\begin{array}{l}\text { Nationwide representative sample of } \\
\text { residents } \geq 18 \mathrm{yr}\end{array}$ & $\begin{array}{l}\text { 1,278 residents recruited in November } \\
2003,4 \text { months after resolution of the } \\
\text { SARS crisis in Taiwan } \\
643(50.3 \%) \mathrm{M}, 635 \text { (49.7\%) F } \\
\text { Mean age: } 41.6 \pm 16.6 \mathrm{yr}\end{array}$ & $\begin{array}{l}\text { - Perceptions and attitudes towards SARS } \\
\text { - Behaviour and SARS-related experiences } \\
\text { - Psychological distress (single-item measure } \\
\text { of degree of distress + Brief Symptom Rating } \\
\text { Scale, i.e. BSRS-5) }\end{array}$ & $\begin{array}{l}\text { Psychological responses } \\
\text { - } 9.2 \% \text { reported that they had become more pessimistic } \\
\text { - Sleep disturbance }(4.2 \%) \text {, anxiety (3.2\%), depression (3.0\%), inferiority (2.9\%), } \\
\text { hostility (2.3\%) } \\
\text { - } 9.7 \% \text { of participants reported that they or their relatives/friends had } \\
\text { encountered SARS-related discrimination. } \\
\text { Coping responses } \\
\text { Decreased preparedness increases pessimism }\end{array}$ \\
\hline 4 & Sim et al (2010) & SARS & $\begin{array}{l}\text { General public who visited community } \\
\text { healthcare centres in Singapore } \\
\text { during the } 2003 \text { SARS outbreak }\end{array}$ & $\begin{array}{l}415 \text { respondents from community } \\
\text { healthcare setting ( } 78 \% \text { response rate) } \\
246(59.3 \%) \mathrm{M} \\
\text { Mean age: } 36.6 \pm 13.9 \mathrm{yr} \\
317(76.4 \%) \text { went to polyclinics for } \\
\text { upper respiratory tract infection }\end{array}$ & $\begin{array}{l}\text { - General Health Questionnaire (i.e. GHQ-28) } \\
\text { - Impact of Events Scale-Revised (i.e. IES-R) } \\
\text { - DSM-IV to determine presence of post- } \\
\text { traumatic stress disorder } \\
\text { - Brief COPE questionnaire }\end{array}$ & $\begin{array}{l}\text { Psychological responses } \\
\text { - Psychiatric morbidity present in } 22.9 \% \text { of participants } \\
\text { - } 25.8 \% \text { had high levels of post-traumatic stress symptoms } \\
\text { Coping responses } \\
\text { - Those with psychiatric morbidity used all coping measures more frequently } \\
\text { than those without } \\
\text { - High levels of post-traumatic stress symptoms associated with increased use } \\
\text { of denial and planning as a coping strategy }\end{array}$ \\
\hline 5 & Mak et al (2009) & SARS & $\begin{array}{l}\text { SARS survivors (Hong Kong Chinese) } \\
\text { from Prince of Wales hospital and } \\
\text { Amoy Garden. Prince of Wales was the } \\
\text { hardest-hit hospital. Amoy Garden } \\
\text { was the hardest-hit residential area } \\
\text { during SARS crisis. }\end{array}$ & $\begin{array}{l}143 \mathrm{SARS} \text { survivors } \\
53 \mathrm{M}, 90 \mathrm{~F} \\
\text { Mean age: } 38.4 \pm 12.4 \mathrm{yr} \\
32.9 \% \text { were healthcare workers } \\
30.1 \% \text { received psychological } \\
\text { counselling after getting SARS }\end{array}$ & $\begin{array}{l}\text { Medical Outcomes Study Social Support Survey } \\
\text { (i.e. MOS-SSS) } \\
\text { - Tangible support } \\
\text { - Affectionate support } \\
\text { - Positive social interaction } \\
\text { - Emotional/informational support } \\
\text { Strategies Used by Patients to Promote Health } \\
\text { (i.e. SUPPH) } \\
\text { - Positive attitude } \\
\text { - Stress reduction } \\
\text { - Making decisions } \\
\text { SF-36 (36-item Short Form) Health Survey } \\
\text { - Mental health } \\
\text { - Role-emotional } \\
\text { - Social functioning }\end{array}$ & $\begin{array}{l}\text { Psychological responses } \\
\text { - Educational level was a significant predictor of mental health status - higher } \\
\text { education predicted better mental health }(p<0.01) \\
\text { - All indicators of medical staff support and perceived family/friend support } \\
\text { were positively correlated with all indicators of mental health status (range } \\
0.20-0.48 \text { ) } \\
\text { Coping responses } \\
\text { - Social support and self-efficacy were associated with better psychological } \\
\text { adjustment } \\
\text { - Suggests that a major component in psychological treatment for survivors of } \\
\text { SARS and infectious diseases is to provide healthcare providers and } \\
\text { individuals' social support network with specific skills that aim to enhance } \\
\text { the patients' perceived efficacy in self care }\end{array}$ \\
\hline
\end{tabular}




\begin{tabular}{|c|c|c|c|c|c|c|}
\hline No. & Author (yr) & ID & Population & Sociodemographic features & Method and Measures used & Main Findings \\
\hline 6 & $\begin{array}{l}\text { Puterman et al } \\
\text { (2009) }\end{array}$ & $\begin{array}{l}\text { SARS and West } \\
\text { Nile Virus }\end{array}$ & General population in Canada & $\begin{array}{l}\text { SARS sample: } 269 \\
\text { West Nile virus sample: } 191\end{array}$ & $\begin{array}{l}\text { - Health behaviours (avoiding people and } \\
\text { taking recommended health precautions) } \\
\text { - Wishful thinking and relationship-focused } \\
\text { coping subscale from the brief Ways of } \\
\text { Coping scale } \\
\text { - Perception of SARS threat } \\
\text { - Empathic coping } \\
\text { - Spielberger's updated version of measure of } \\
\text { state anxiety }\end{array}$ & $\begin{array}{l}\text { Psychological responses } \\
\text { Anxiety } \\
\text { Coping responses } \\
\text { - For both samples, perception of threat, coping (empathetic responding and } \\
\text { wishful thinking) and health behaviours were all positively related to one } \\
\text { another } \\
\text { - Individuals higher in threat perception were more likely to report employing } \\
\text { both modes of coping and engaging in greater health behaviours }\end{array}$ \\
\hline 7 & Chan et al (2007) & SARS & $\begin{array}{l}\text { Parents of highly suspected SARS } \\
\text { paediatric patients in Hong Kong } \\
\text { between March } 20 \text { and May 28, } 2003\end{array}$ & $\begin{array}{l}7 \text { parents (response rate of } 41 \% \text { ) of } \\
\text { highly suspected SARS patients }\end{array}$ & Qualitative, semi-structured interviews & $\begin{array}{l}\text { Psychological responses } \\
\text { Fear of immediate isolation and infection control procedures, fear of phone } \\
\text { calls from hospital } \\
\text { Coping responses } \\
\text { Distractions (going out and buying child's favourite foods); most parents did } \\
\text { not seek support from other family members, believing that the community } \\
\text { was already stressed because of SARS, brought personal items to the } \\
\text { hospitalised child frequently }\end{array}$ \\
\hline 8 & $\begin{array}{l}\text { Chiang et al } \\
\text { (2007) }\end{array}$ & SARS & $\begin{array}{l}\text { Nurses caring for patients with SARS } \\
\text { during the outbreak in Taipei and } \\
\text { were infected }\end{array}$ & $\begin{array}{l}21 \text { nurses (15 ER nurses, } 6 \text { from } \\
\text { respiratory ICUs) } \\
\text { Age: } 21-43 \mathrm{yr}\end{array}$ & 4 focus group sessions & $\begin{array}{l}\text { Psychological responses } \\
\text { Concerns about health of self/family } \\
\text { Coping responses } \\
\text { Ethical love prompted nurses to think about caregiving in a new light; } \\
\text { caregiving with compassion, collaboration with staff }\end{array}$ \\
\hline 10 & $\begin{array}{l}\text { Yeung et al } \\
\text { (2007) }\end{array}$ & SARS & Nationwide sample age: $\geq 18 \mathrm{yr}$ & $\begin{array}{l}\text { Phase } 1 \\
741 \text { responded ( } 62.5 \% \text { response rate) to } \\
\text { the survey conducted between March } \\
\text { and April } 2003 \text { when the SARS outbreak } \\
\text { was most serious in Hong Kong } \\
\text { - Younger group ( } 18-35 \mathrm{yr}), \mathrm{n}=351 \\
\text { - Middle-aged group }(36-55 \mathrm{yr}), \mathrm{n}= \\
201 \\
\text { - Older group (> } 56 \mathrm{yr}), \\
\mathrm{n}=189 \\
\text { - } 62 \% \mathrm{~F} \\
\text { Phase } 2 \\
385(52 \%) \text { participants from Phase } 1 \\
\text { participated in Phase 2, which was } \\
\text { carried out between May and June } 2003 \\
\text { after the SARS outbreak had ended }\end{array}$ & $\begin{array}{l}\text { Emotional responses (extent they felt sadness, } \\
\text { fear, anger, and shock) } \\
\text { Brief COPE questionnaire }\end{array}$ & $\begin{array}{l}\text { Psychological responses } \\
\text { - Older adults had lowest level of anger in both phases }(2.13 \pm 1.46 \text { in Phase } 1 \\
\text { and } 1.57 \pm 1.07 \text { in Phase } 2) \\
\text { - Younger }(2.54 \pm 1.28) \text { and middle-aged adults }(2.02 \pm 1.48) \text { experienced the } \\
\text { highest levels of anger in Phase } 1 \text { and } 2 \text { respectively } \\
\text { Coping strategies } \\
\text { - Younger adults }(2.11 \pm 0.77) \text { used greater emotion-focused coping than } \\
\text { older ( }(1.77 \pm 0.54) \text { and middle aged adults }(1.83 \pm 0.62) \text { at Phase } 1 \\
\text { - Older adults }(2.92 \pm 0.54) \text { used more emotion-focused coping than younger } \\
\text { adults }(2.72 \pm 0.50) \text { at Phase } 2\end{array}$ \\
\hline
\end{tabular}




\begin{tabular}{|c|c|c|c|c|c|c|}
\hline No. & Author (yr) & ID & Population & Sociodemographic features & Method and Measures used & Main Findings \\
\hline 11 & $\begin{array}{l}\text { Cheng et al } \\
\text { (2006a) }\end{array}$ & SARS & $\begin{array}{l}\text { SARS survivors, family members, and a } \\
\text { non-affected sample from Hong Kong }\end{array}$ & $\begin{array}{l}\text { Qualitative interview and quantitative } \\
\text { survey } \\
\text { - } 70 \text { SARS survivors }(33 \mathrm{M}, 37 \mathrm{~F}) \\
\text { - } 59 \text { family members }(24 \mathrm{M}, 35 \mathrm{~F}) \text { of } \\
\text { SARS survivors } \\
\text { - } 17 \text { healthy adults }(75 \mathrm{M}, 97 \mathrm{~F}) \text { not } \\
\text { affected by SARS outbreak }\end{array}$ & $\begin{array}{l}\text { - Qualitative interview and quantitative survey } \\
\text { Marlowe-Crowne Social Desirability Scale } \\
\text { measured defensiveness/denial } \\
\text { - Rosenberg Self-Esteem Scale } \\
\text { - Inventory of Socially Supportive Behaviours } \\
\text { measured social support received }\end{array}$ & $\begin{array}{l}\text { Psychological responses } \\
\text { Defensiveness } \\
\text { Coping responses } \\
\text { Seeking social support }\end{array}$ \\
\hline 12 & $\begin{array}{l}\text { Cheng et al } \\
\text { (2006b) }\end{array}$ & SARS & $\begin{array}{l}\text { Hong Kong Chinese SARS survivors, } \\
\text { including healthcare workers }\end{array}$ & $\begin{array}{l}\text { 57 Hong Kong Chinese SARS survivors } \\
\text { who were discharged from Princess } \\
\text { Margaret Hospital for } 2-6 \text { months } \\
\text { - } 38 \mathrm{~F}(66.7 \%) \text { and } 19 \mathrm{M}(33.3 \%) \\
\text { - } 38.1 \pm 10.4 \mathrm{yr} \\
\text { - } 22(38.6 \%) \text { were healthcare workers }\end{array}$ & $\begin{array}{l}\text { - Beck Depression Inventory } \\
\text { - Beck Anxiety Inventory } \\
\text { - SARS Appraisal Inventory } \\
\text { - Perceived impact of SARS (primary } \\
\text { appraisal) } \\
\text { - Coping efficacy (secondary appraisal) } \\
\text { - Higher scores = more negative appraisal } \\
\text { - Post-traumatic growth measured using } \\
\text { Thriving Scale } \\
\text { - Personal growth } \\
\text { - Spiritual growth } \\
\text { - Relationship growth }\end{array}$ & $\begin{array}{l}\text { Psychological responses } \\
\text { - Scores on SARS Appraisal Inventory were positively correlated with scores on } \\
\text { Beck Depression Inventory and Beck Anxiety Inventory, and negatively } \\
\text { correlated with perceived health } \\
\text { - Post-traumatic growth scores were negatively correlated with depression } \\
\text { scores, non-significantly with anxiety symptoms, and positively with } \\
\text { perceived health } \\
\text { - Healthcare workers had higher anxiety ( } \mathrm{t}=2.53, \mathrm{p}<0.05) \text { and depression } \\
\text { scores }(\mathrm{t}=2.03, \mathrm{p}<0.05) \\
\text { Coping responses } \\
\text { 'Perceived impact' and 'coping efficacy' had direct effects on Beck Depression } \\
\text { Inventory, Beck Anxiety Inventory and perceived health }\end{array}$ \\
\hline 13 & $\begin{array}{l}\text { Cheng \& Cheung } \\
\text { (2005) }\end{array}$ & SARS & $\begin{array}{l}\text { Hong Kong undergraduates assessed } \\
\text { at } 4 \text { time points ( } 4 \text { weeks) }+1 \text { at } \\
\text { baseline (previous study) }\end{array}$ & $\begin{array}{l}72 \text { Hong Kong Chinese undergraduates } \\
31 \mathrm{M}, 41 \mathrm{~F} \\
\text { Mean age: } 21.14 \pm 0.99 \mathrm{yr}\end{array}$ & $\begin{array}{l}\text { - State-Trait Anxiety Inventory } \\
\text { - Coping Flexibility Inventory } \\
\text { - Controllable events } \\
\text { - Uncontrollable events } \\
\text { - Strategies for coping with SARS (based on } \\
\text { previous elicitation study) } \\
\text { - Personal hygiene practice } \\
\text { - Lifestyle habits } \\
\text { - Information seeking } \\
\text { - Avoidance }\end{array}$ & $\begin{array}{l}\text { Psychological responses } \\
\text { - Trait anxiety was able to predict fluctuations in state anxiety across } \\
\text { timepoints }(p<0.05) \\
\text { - However, the positive association between trait and state anxiety was only } \\
\text { present at initial time points } \\
\text { - Individual differences in state anxiety became minimal at subsequent time } \\
\text { points } \\
\text { Coping responses } \\
\text { - Situation-specific coping strategies of personal hygiene practice }(p<0.05) \\
\text { and avoidance }(p=0.001) \text { were found to predict fluctuations in state anxiety } \\
\text { more than lifestyle habits and information-seeking behaviour } \\
\text { - Individuals who used more avoidant coping strategies experienced less state } \\
\text { anxiety }(\beta=-0.57)\end{array}$ \\
\hline 14 & Lee et al (2005) & SARS & $\begin{array}{l}15 \text { residents, 4,896 households in } \\
\text { Amoy Gardens }\end{array}$ & $\begin{array}{l}903 \text { completed questionnaires }(18.5 \% \\
\text { response rate) } \\
\text { - } 41 \% \mathrm{M} \\
\text { - Mean age: } 31.9 \mathrm{yr} \\
\text { - } 5.2 \% \text { ex-SARS patients } \\
\text { - } 7.7 \% \text { had confirmed SARS cases in } \\
\text { their households } \\
15 \text { residents for focus group }\end{array}$ & $\begin{array}{l}\text { Two focus groups with } 15 \text { residents in Amoy } \\
\text { Gardens } \\
\text { Self-report questionnaire generated from a } \\
\text { content analysis of the focus groups } \\
\text { (experience of stigma and coping, } \\
\text { psychosomatic symptoms) }\end{array}$ & $\begin{array}{l}\text { Psychological responses } \\
\text { Rejection from dining by friends }(40.6 \%) \text {, discrimination by employers } \\
\text { (48.7\%), persistent low mood }(73.1 \%) \text {, irritability (56.7\%), insomnia (34.2\%) } \\
\text { Coping responses } \\
\text { Avoid outbreak areas, conceal residential status }\end{array}$ \\
\hline 15 & Mok et al (2005) & SARS & $\begin{array}{l}\text { Nurses who contracted SARS in Hong } \\
\text { Kong }\end{array}$ & 10 nurses $(2 \mathrm{M}, 8 \mathrm{~F})$ & Qualitative study & $\begin{array}{l}\text { Psychological responses } \\
\text { Anxiety due to uncertainty about the disease, fear of death, sense of } \\
\text { powerfulness and loss of control, feelings of anger and guilt, isolation and } \\
\text { loneliness } \\
\text { Coping responses } \\
\text { Social support, religious practices, faith, prayer, reflection }\end{array}$ \\
\hline 16 & Qian et al (2005) & SARS & $\begin{array}{l}\text { College students in Beijing and } \\
\text { Suzhou who were under different } \\
\text { external stressors during the } \\
\text { SARS outbreak in China from } 22 \text { April } \\
\text { to } 23 \text { June } 2003\end{array}$ & $\begin{array}{l}\text { - } 268 \text { college students in Beijing ( } 141 \\
\text { M, } 127 \mathrm{~F}) \\
\text { Age: } 22.73 \pm 2.90 \mathrm{yr} \\
\text { - } 397 \text { undergraduates from Suzhou } \\
\text { Medical University }(176 \mathrm{M}, 221 \mathrm{~F}) \\
\text { Age: } 20.6 \pm 1.2 \mathrm{yr}\end{array}$ & $\begin{array}{l}\text { Psychological responses questionnaire on } \\
\text { SARS }\end{array}$ & $\begin{array}{l}\text { Psychological responses } \\
\text { College students in Beijing showed higher scores for negative cognitions and } \\
\text { negative emotions towards SARS than those in Suzhou }(p<0.001) \\
\text { Coping responses } \\
\text { More coping behaviours in Beijing sample than Suzhou sample }(p<0.001) \text { (e.g. } \\
\text { wearing face mask, monitoring temperature) }\end{array}$ \\
\hline
\end{tabular}




\begin{tabular}{|c|c|c|c|c|c|c|}
\hline No. & Author (yr) & ID & Population & Sociodemographic features & Method and Measures used & Main Findings \\
\hline 17 & $\begin{array}{l}\text { Cheng et al } \\
\text { (2004) }\end{array}$ & SARS & SARS survivors after 1-month recovery & $\begin{array}{l}\text { 100 SARS survivors }(37.2 \% \text { response } \\
\text { rate) } \\
\text { - Mean age: } 37.14 \pm 12.09 \mathrm{yr} \\
\text { - } 66 \mathrm{~F}, 34 \mathrm{M} \\
\text { } 18 \% \text { healthcare workers } \\
184 \text { community subjects }(92 \% \text { response } \\
\text { rate) } \\
\text { - Mean age: } 34.51 \pm 8.71 \mathrm{yr} \\
\text { - } 111 \mathrm{~F}, 73 \mathrm{M} \\
\text { - } 10.9 \% \text { healthcare workers }\end{array}$ & $\begin{array}{l}\text { - General Health Questionnaire-28 (i.e. GHQ- } \\
\text { 28) } \\
\text { - Rosenberg Self-Esteem Scale } \\
\text { - World Health Organization Quality of Life } \\
\text { measure abbreviated version } \\
\text { - Severity of SARS symptoms } \\
\text { - Level of social support }\end{array}$ & $\begin{array}{l}\text { Psychological responses } \\
\text { - } 68 \% \text { of SARS survivors were identified as distressed using a cutoff score of } 5 \text {, } \\
\text { compared to } 34.8 \% \text { in the community sample (OR } 2.89,95 \% \mathrm{Cl} 1.73-4.82, \mathrm{p}< \\
0.001 \text { ) } \\
\text { - SARS survivors had elevated scores in the GHQ-28 and } 3 \text { subscales (somatic } \\
\text { symptoms, anxiety-insomnia, social dysfunction) as compared to the } \\
\text { community subjects } \\
\text { - SARS survivors had lower quality of life (total, physical, psychological and } \\
\text { environment) as compared to community subjects } \\
\text { Coping responses } \\
\text { Social support }\end{array}$ \\
\hline 18 & Leung et al (2003) & SARS & $\begin{array}{l}\text { Community sample in Hong Kong, } \\
\text { conducted at the height of the SARS } \\
\text { outbreak from } 29 \text { March to } 6 \text { April } \\
2003\end{array}$ & $\begin{array}{l}1,115 \text { Hong Kong adult residents }(76.4 \% \\
\text { response rate) } \\
42.9 \% \mathrm{M}\end{array}$ & Survey & $\begin{array}{l}\text { Psychological responses } \\
\text { - Mean anxiety level }=2.24 \text { (on a scale of } 1 \text { to } 4 \text {, with } 4 \text { being 'very anxious') } \\
1 \text { ( }(12.6 \%) \text { in } 8 \text { respondents had a mean score of } \geq 3 \text {, indicating they were } \\
\text { 'quite'/'very' anxious } \\
\text { Coping responses } \\
\text { Adoption of precautionary measures }\end{array}$ \\
\hline 19 & $\begin{array}{l}\text { Schwerdtle et al } \\
\text { (2017) }\end{array}$ & Ebola & $\begin{array}{l}\text { Adult males and females who } \\
\text { contracted Ebola, became sick, } \\
\text { survived between } 2014 \text { and 2015, and } \\
\text { were treated in an Ebola treatment } \\
\text { centre }\end{array}$ & $\begin{array}{l}\text { Group 1: } 6 \text { participants who were } \\
\text { members of a rural community from } \\
\text { Sierra Leone (set up their own Ebola } \\
\text { survivor self-help group which ran from } \\
\text { an empty healthcare centre) } \\
\text { Group 2: } 12 \text { participants who were } \\
\text { members of a small rural village in Sierra } \\
\text { Leone that suffered a loss of } 10 \% \text { of the } \\
\text { village population due to the outbreak } \\
\text { Group 3: } 7 \text { participants from an urban } \\
\text { setting in Liberia and who were mostly } \\
\text { admitted around the peak of the } \\
\text { outbreak between July and September } \\
\text { 2014 } \\
\text { Total: } 25\end{array}$ & $\begin{array}{l}\text { Qualitative semi-structured group interview, } \\
\text { one group at a time }\end{array}$ & $\begin{array}{l}\text { Psychological responses } \\
\text { - Multiplicity of deaths causing grief, loss } \\
\text { - Sense of abandonment, stigmatisation } \\
\text { Coping responses } \\
\text { - Self and community protection and care } \\
\text { - Seeking complementary medicine, strength in religion } \\
\text { - Coping resources and activities - running away to another town, seeking } \\
\text { complementary medicine, treating patients at home when healthcare } \\
\text { services were not accessible }\end{array}$ \\
\hline 20 & $\begin{array}{l}\text { Rabelo et al } \\
\text { (2016) }\end{array}$ & Ebola & $\begin{array}{l}\text { Survivors of Ebola treated at an Ebola } \\
\text { Treatment Unit (ETU) managed by } \\
\text { Médecins Sans Frontières }\end{array}$ & $\begin{array}{l}\text { Group 1: } 9 \text { female survivors of Ebola } \\
\text { Group 2: } 8 \text { male survivors } \\
\text { Group 3: } 6 \text { male survivors from Group 2 }\end{array}$ & $\begin{array}{l}\text { Qualitative study, focus group discussions after } \\
\text { discharge }\end{array}$ & $\begin{array}{l}\text { Psychological responses } \\
\text { - Concerns about family life outside the ETU, isolation, uncertainty } \\
\text { - Loss of sense of reality in the ETU, loss of loved ones, possessions, depression } \\
\text { Stigmatisation } \\
\text { - Post-traumatic stress } \\
\text { Coping responses } \\
\text { Seeking support from religious leader, peer, staff, family, friends }\end{array}$ \\
\hline 21 & $\begin{array}{l}\text { Matua \& Van der } \\
\text { Wal (2015) }\end{array}$ & Ebola & $\begin{array}{l}\text { Survivors and family caregivers after } \\
\text { an Ebola outbreak in Kibale District, } \\
\text { Western Uganda }\end{array}$ & $\begin{array}{l}12 \text { adult survivors and their family } \\
\text { caregivers } \\
5 \text { survivors - mean age: } 38 \mathrm{yr} \\
7 \text { caregivers - mean age: } 33 \mathrm{yr}\end{array}$ & In-depth semi-structured qualitative interviews & $\begin{array}{l}\text { Psychological responses } \\
\text { - Fear, ostracism and stigmatisation } \\
\text { - Helplessness and desperation } \\
\text { - Social isolation, fear and sadness } \\
\text { - Psychosomatic manifestations } \\
\text { Coping responses } \\
\text { - Seeking self-preservation and protection } \\
\text { - Positive attitude and prayer }\end{array}$ \\
\hline
\end{tabular}




\begin{tabular}{|c|c|c|c|c|c|c|}
\hline No. & Author (yr) & ID & Population & Sociodemographic features & Method and Measures used & Main Findings \\
\hline 23 & Taha et al (2014) & H1N1 & $\begin{array}{l}\text { Individuals recruited from online sites } \\
\text { from } 8 \text { October } 2009 \text { to } 29 \text { November } \\
2009 \text { during the peak of the H1N } 1 \\
\text { epidemic }\end{array}$ & $\begin{array}{l}1,027 \text { individuals } \geq 18 \text { years old } \\
748(72.83 \%) \mathrm{F} \text { - age: } 32.37 \pm 10.23 \mathrm{yr} \\
279(27.17 \%) \mathrm{M} \text { - age: } 31.08 \pm 10.38 \mathrm{yr}\end{array}$ & $\begin{array}{l}\text { - Intolerance of uncertainty } \\
\text { - Stress appraisal } \\
\text { - Coping scale } \\
\text { - State-trait anxiety inventory }\end{array}$ & $\begin{array}{l}\text { Psychological responses } \\
\text { Anxiety, uncertainty } \\
\text { Coping responses } \\
\text { - Problem and emotion-focused coping } \\
\text { - H1N1 anxiety was directly predicted by threat and self-control appraisals and } \\
\text { endorsement of emotion- and problem-focused coping }\end{array}$ \\
\hline 24 & $\begin{array}{l}\text { McCauley et al } \\
\text { (2013) }\end{array}$ & H1N1 & $\begin{array}{l}\text { Participants aged } \geq 25 \text { yr from various } \\
\text { ethnic, racial and socioeconomic } \\
\text { positions in New England }\end{array}$ & $\begin{array}{l}16 \text { participants from City A } \\
\text { - } 9 \mathrm{~F}, 7 \mathrm{M} \\
\text { - Mean age: } 45 \mathrm{yr} \\
9 \text { participants from City B } \\
\text { - } 6 \mathrm{~F}, 3 \mathrm{M} \\
\text { - Mean age: } 53 \mathrm{yr} \\
10 \text { participants from City C } \\
\text { - } 6 \mathrm{~F}, 4 \mathrm{M} \\
\text { - Mean age: } 45 \mathrm{yr} \\
11 \text { participants from City D } \\
\text { - } 8 \mathrm{~F}, 3 \mathrm{M} \\
\text { - Mean age: } 61 \mathrm{yr}\end{array}$ & Qualitative study with focus groups & $\begin{array}{l}\text { Psychological responses } \\
\text { Blaming authorities, sense of isolation, helplessness, stigmatisation } \\
\text { Coping responses } \\
\text { Avoidance, lack of trust, problem solving, religious faith }\end{array}$ \\
\hline
\end{tabular}

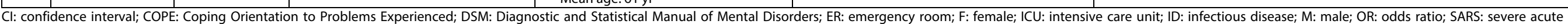
respiratory syndrome 
Supplementary Table II. Quality appraisal of quantitative studies and mixed methods studies.

\begin{tabular}{|c|c|c|c|c|c|c|c|c|c|c|c|c|}
\hline Study & Purpose & \begin{tabular}{|l|} 
Literature review \\
\end{tabular} & \begin{tabular}{|l|l}
$\begin{array}{l}\text { Research } \\
\text { design }\end{array}$ \\
\end{tabular} & $\begin{array}{l}\text { Sample size, } \\
\text { description }\end{array}$ & $\begin{array}{l}\text { Valid, reliable } \\
\text { outcome measures }\end{array}$ & Data analysis & \begin{tabular}{|l|} 
Results, statistical \\
significance
\end{tabular} & \begin{tabular}{|l|} 
Dropouts/ \\
exclusions
\end{tabular} & \begin{tabular}{|l|} 
Clinical \\
importance
\end{tabular} & \begin{tabular}{|l|} 
Conclusion \\
\end{tabular} & \begin{tabular}{|l} 
Limitations \\
\end{tabular} & $\begin{array}{l}\text { Score out of } \\
12\end{array}$ \\
\hline Cheng \& Cheung (2005) & $\sqrt{ }$ & $\checkmark v$ & $\sqrt{ }$ & $\checkmark$ & $\sqrt{ }$ & $\checkmark$ & $\sqrt{ }$ & $\checkmark v$ & $\sqrt{ }$ & $\checkmark v$ & $\checkmark$ & 12 \\
\hline Cheng et al (2004b) & $\sqrt{ }$ & $\sqrt{ }$ & $\checkmark$ & $\checkmark$ & $\sqrt{ }$ & $\checkmark$ & $\checkmark$ & $\sqrt{ }$ & $\checkmark$ & $\checkmark$ & $\checkmark$ & 12 \\
\hline Cheng et al (2006a) & $\sqrt{ }$ & $\sqrt{ }$ & $\checkmark v$ & $\checkmark v$ & $\sqrt{ }$ & $\checkmark$ & 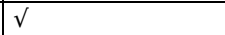 & $\sqrt{ }$ & $\checkmark v$ & $\checkmark v$ & $\checkmark$ & 12 \\
\hline Cheng et al (2006b) & $\sqrt{ }$ & $\sqrt{ }$ & $\checkmark v$ & $\sqrt{ }$ & $\sqrt{ }$ & $\checkmark$ & $\sqrt{ }$ & $\sqrt{ }$ & $\checkmark v$ & $\checkmark v$ & $\checkmark$ & 12 \\
\hline Lee et al (2005) & $\sqrt{ }$ & $\checkmark v$ & $\checkmark$ & $\checkmark$ & $\sqrt{ }$ & $\checkmark$ & $\sqrt{ }$ & $\checkmark v$ & $\sqrt{ }$ & $\checkmark$ & $\sqrt{ }$ & 12 \\
\hline Leung et al (2003) & $\sqrt{ }$ & $\checkmark$ & $\checkmark$ & $\sqrt{ }$ & $\sqrt{ }$ & $\checkmark$ & $\sqrt{ }$ & $\checkmark$ & $\sqrt{ }$ & $\checkmark$ & $\checkmark$ & 12 \\
\hline Main et al (2011) & $\sqrt{ }$ & $\checkmark$ & $\checkmark$ & $\checkmark$ & $\sqrt{ }$ & $\checkmark$ & $\sqrt{ }$ & - & $\sqrt{ }$ & $\checkmark$ & $\checkmark$ & 11 \\
\hline Mak et al (2009) & $\sqrt{ }$ & $\checkmark$ & v & $\checkmark$ & $\checkmark$ & $\checkmark$ & $\sqrt{ }$ & - & $\sqrt{ }$ & $\checkmark$ & v & 11 \\
\hline \begin{tabular}{|l|} 
Peng et al (2010) \\
\end{tabular} & $\sqrt{ }$ & $\sqrt{ }$ & $\sqrt{ }$ & $\sqrt{ }$ & $\sqrt{ }$ & $\sqrt{ }$ & $\sqrt{ }$ & $\checkmark v$ & $\sqrt{ }$ & $\sqrt{ }$ & $\sqrt{ }$ & 12 \\
\hline Qian et al (2005) & $\sqrt{ }$ & $\sqrt{ }$ & $\checkmark$ & $\checkmark$ & - & $\checkmark$ & $\checkmark$ & - & $\checkmark$ & $\checkmark$ & $\checkmark$ & 10 \\
\hline Sim et al (2010) & $\checkmark$ & $\checkmark$ & $\checkmark$ & $\checkmark$ & $\checkmark$ & $\checkmark v$ & v & $\checkmark v$ & $\checkmark$ & v & $\checkmark$ & 12 \\
\hline Taha et al (2014) & $\checkmark$ & $\checkmark$ & v & $\checkmark v$ & $\checkmark$ & $\checkmark v$ & v & - & $\checkmark$ & v & v & 11 \\
\hline Yeung \& Fung (2007) & $\checkmark$ & $\checkmark v$ & $\checkmark$ & $\checkmark v$ & $\checkmark$ & $\checkmark v$ & $\sqrt{ }$ & $\checkmark v$ & $\checkmark$ & V & V & 12 \\
\hline
\end{tabular}


Supplementary Table III. Quality appraisal of qualitative studies and mixed methods studies.

\begin{tabular}{|c|c|c|c|c|c|c|c|c|c|c|c|}
\hline Study & Purpose & Rationale & $\begin{array}{l}\text { Conceptual } \\
\text { framework }\end{array}$ & $\begin{array}{l}\text { Ethical } \\
\text { considerations }\end{array}$ & Sampling strategy & Data collection & $\begin{array}{l}\text { Data management } \\
\text { procedure }\end{array}$ & $\begin{array}{l}\text { Data analysis } \\
\text { method }\end{array}$ & $\begin{array}{l}\text { Threat to reliability, } \\
\text { validity }\end{array}$ & Conclusion & Score out of 10 \\
\hline Chan et al (2007) & $\checkmark$ & $\checkmark$ & $\checkmark$ & $\checkmark$ & $\checkmark$ & $\checkmark$ & $\checkmark$ & $\checkmark$ & $\checkmark$ & $\checkmark$ & 10 \\
\hline Cheng et al (2006a) & $\checkmark$ & $\checkmark$ & $\checkmark$ & $\checkmark$ & $\checkmark$ & $\checkmark$ & - & $\checkmark$ & $\checkmark$ & $\checkmark$ & 9 \\
\hline Chiang et al (2007) & $\checkmark$ & $\sqrt{ }$ & $\sqrt{ }$ & $\sqrt{ }$ & $\sqrt{ }$ & $\checkmark$ & $\checkmark$ & $\sqrt{ }$ & - & $\checkmark$ & 9 \\
\hline Dodgson et al (2010) & $\checkmark$ & $\sqrt{ }$ & $\checkmark$ & $\sqrt{ }$ & $\checkmark$ & $\sqrt{ }$ & $\checkmark$ & $\sqrt{ }$ & $\checkmark$ & $\checkmark$ & 10 \\
\hline Joffe \& Haarhoff (2002) & $\checkmark$ & $\sqrt{ }$ & $\checkmark$ & - & $\checkmark$ & $\checkmark$ & $\checkmark$ & $\checkmark$ & $\checkmark$ & $\sqrt{ }$ & 9 \\
\hline Lee et al (2005) & $\checkmark$ & $\checkmark$ & $\sqrt{ }$ & $\sqrt{ }$ & $\sqrt{ }$ & $\sqrt{ }$ & $\sqrt{ }$ & - & $\bar{v}$ & $\sqrt{ }$ & 9 \\
\hline Matua \& Van Der Wal (2015) & $\checkmark$ & $\sqrt{ }$ & $\checkmark$ & $\sqrt{ }$ & $\checkmark$ & $\checkmark$ & $\checkmark$ & $\checkmark$ & $\checkmark$ & $\checkmark$ & 10 \\
\hline McCauley et al (2013) & $\checkmark$ & $\checkmark$ & $\checkmark$ & $\checkmark$ & $\checkmark$ & $\checkmark$ & $\checkmark$ & $\checkmark$ & $\checkmark$ & $\checkmark$ & 10 \\
\hline Mok et al (2005) & $\checkmark$ & $\checkmark$ & $\checkmark$ & $\checkmark$ & $\checkmark$ & $\checkmark$ & $\checkmark$ & $\checkmark$ & $\checkmark$ & $\checkmark$ & 10 \\
\hline Rabelo et al (2016) & $\checkmark$ & $\checkmark$ & $\checkmark$ & $\checkmark$ & $\checkmark$ & $\checkmark$ & $\checkmark$ & $\checkmark$ & $\checkmark$ & $\checkmark$ & 10 \\
\hline Schwerdtle et al (2017) & $\checkmark$ & $\sqrt{ }$ & $\checkmark$ & $\sqrt{ }$ & $\checkmark$ & $\checkmark$ & $\sqrt{ }$ & $\checkmark$ & $\checkmark$ & $\checkmark$ & 10 \\
\hline Siu et al (2007) & $\checkmark$ & $\sqrt{ }$ & $\checkmark$ & $\sqrt{ }$ & $\checkmark$ & $\checkmark$ & $\checkmark$ & $\checkmark$ & $\checkmark$ & $\sqrt{ }$ & 10 \\
\hline
\end{tabular}

